
ВИСЛОВЛЮВАННЯ Й ТЕКСТУ

DOI 10.31558/2075-2970.2018.35-36.6

УДК 811.111’373.612.2

(C) О. В. Боднар

(Вінниця)

\title{
АНТРОПОМОРФНІ МЕТАФОРИ У АНГЛОМОВНИХ ТЕКСТАХ ІНФОРМАЦІЙНО-ПУБЛІЦИСТИЧНОГО ЖАНРУ
}

Статтю присвячено вивченню антропоморфної метафори, основою якої є перенесення рис одного об'єкта на інший. Оскільки одним із основних джерел створення нових метафор $є$ інформаційно-публіцистичні тексти, дослідження, вивчення та класифікації метафор за типами є актуальним саме в цьому жанрі. Особлива увага приділяється метафоричним моделям перенесення рис. Мета статті - з'ясувати комунікативні та структурно-семантичні закономірності створення метафор у газетно-публіцистичних текстах в англійській мові. Матеріалом дослідження в статті виступають метафоричні утворення, отримані методом суцільної вибірки iз видань газет «The Economist» за 2013, 2014 та 2017 роки. Автор робить висновок, що найбільш продуктивним створення нових метафор є, якщо джерелом запозичення рис перенесення виступають фізіологічні характеристики людини. Подальшою перспективою є дослідження інших типів метафор у інформаційно-публіцистичних текстах англійською мовою.

Ключові слова: метафора, метафоричні моделі перенесення, антропоморфна метафора, інформаційно-публіцистичні тексти, джерело метафоричного перенесення, ціль метафоричного перенесення.

Одну із важливих і провідних ролей сучасного інформаційного середовища відіграють засоби масової інформації, що формуються та змінюються впродовж розвитку соціуму і мають безпосередній значний вплив на суспільні норми. Кожен із видів ЗМІ застосовує вербальні засоби комунікації, що уможливлюють інформування широких мас і здійснюють вплив на аудиторію. Ключове місце в цьому посідає метафора, основою якої є перенесення імені одного об’єкта на інший, причому ці об'єкти можуть належати до різних тематичних та понятійних сфер. Оскільки одним із основних джерел створення нових метафор є інформаційнопубліцистичні тексти, дослідження, вивчення та класифікації метафор за типами є актуальним саме в цьому жанрі.

Метафору досліджували багато мовознавців та лінгвістів, філософів та науковців, зокрема Дж. Лакофф (Лакофф, 1995), М. Джонсон (Лакофф, Джонсон, 1990), Г. М. Скляревська (Скляревская, 1993), Н. Д. Артуюнова (Артуюнова, 1990), Н. Д. Бессарабова (Бессарабова, 1987), М. Брідслі (Бридсли, 1990), Н. В. Кабанчук (Кабанчук, 2014).

Мета дослідження - з'ясувати комунікативні та структурно-семантичні закономірності створення метафор у газетно-публіцистичних текстах в англійській мові. Об'єктом дослі- 
дження є метафора в сучасних англійських інформаційно-публіцистичних текстах. Предмет дослідження - моделі перенесення рис одного об’єкта на інший у створенні метафор.

Методологічною основою стали роботи Дж. Лакофф (Лакофф, 1995), М. Джонсон (Лакофф, Джонсон, 1990), Г. Н. Скляревської (Скляревская, 1993).

Матеріал дослідження - метафоричні утворення, отримані методом суцільної вибірки із видань газет «The Economist» за 2013, 2014 та 2017 роки. Поставлені мета і завдання вимагають комплексного підходу до методів дослідження. Основним методом дослідження став метод лінгвістичного опису, використано також методи структурного та статистичного аналізу. Для наочності і кращого розуміння до нижче проаналізованих речень із метафорами буде додано переклад українською мовою, в якому підкресленням виділено дослівний переклад метафори, а в квадратних дужках адаптований до норм української мови переклад.

Метафори, які формують матеріал дослідження поділяються на декілька підгруп відповідно до джерел перенесення рис. В рамках кожної із цих моделей буде описано механізм перенесення рис одного об'єкта на інший (ціль перенесення).

У статті викладено частину більш масштабного дослідження метафор, а саме дослідження антропоморфного типу метафор, оскільки після підрахунків частотності вживання стало очевидним, що цей тип є одним із найпоширеніших $(84,1$ \% від загальної кількості вибірки, котра налічувала 750 одиниць). Він налічує 631 метафору, які було розподіллено за спільним джерелом перенесення риси на три окремих групи: перша- метафори і джерелом перенесення, що позначає фізіологічні характеристики та особливості людини; друга- метафори, де джерелом перенесення $є$ фізичні параметри людини; третя - джерелом виступають психічні характеристики. Згідно з підрахунками, найпродуктивнішими моделями перенесення є ті, що використовують фізіологічні особливості в якості джерела запозичення рис.

Структурно-семантичний антропоморфний тип включає в себе метафори, в межах яких перенесення було здійснено з такого джерела як характеристики людини, її уміння та навички. В газетно-публіцистичних текстах для опису та характеристики предметів часто використовують лексику зі сфери опису людей, їх зовнішності, рис характеру, здібностей та умінь. Антропоморфний тип у текстах випусків журналу «The Economist» налічує чотирнадцять моделей. Моделі перенесення відрізняються ціллю перенесення риси, але мають спільне загальне джерело. Саме за спільним джерелом перенесення антропоморфні метафори було розділено на наступні групи: метафори із джерелом перенесення фізіологічних рис, психологічних рис та фізичних рис.

На дві різні групи було розподіллено метафори із джерелом перенесення фізичних та фізіологічних рис. Фізіологічне джерело охоплює слова на позначення рис, що розкривають ме- 
ханізми здійснення функцій організму (ріст, розмноження, розвиток, дихання і т. д.), їх зв’язку між собою, регуляцію, пристосування до навколишнього середовища, становлення в процесі розвитку та індивідуального особистісного розвитку. До фізичного джерела відносяться слова на позначення фізичних характеристик та параметрів організму людини, до його будови та зовнішнього вигляду. До групи із джерелом психічних рис належать метафори, в яких перенесені риси пов'язані із внутрішнім світом людини, іiї настроєм, почуттям, душевним станом.

Перша група метафор охоплює метафори із джерелом перенесення фізіологічних особливостей людини. Подібний спосіб опису економічних, адміністративно-географічних та інших понять чи то явищ (використання фізіологічних особливостей людини), є досить поширеним. Він допомагає створити яскравий та зрозумілий метафоричний образ. Ця група налічує 9 моделей перенесення, розглянутих нижче.

Модель 1: фізіологічні особливості людини $\rightarrow$ слово на позначення адміністративногеографічного поняття.

- India has until recently grown faster than all other big emerging economy. - До недавнього часу, Індія росла [економіка Індії розвивалася] швидше за будь-яку іншу новоутворену економіку.

В наведеному прикладі відбулося перенесення фізіологічної здатності людини рости (grow) на ціль перенесення, а саме на слово, що позначає адміністративно-географічне поняття (India). Це перенесення було використано з метою зобразити процес економічного розвитку країни. Цей приклад також містить в собі ще одне метафоричне перенесення: у слові на позначення адміністративно-географічного поняття India в контексті чітко видно перенесення із слова на позначення економічного поняття есопоту.

Модель 2: фізіологічні особливості людини $\rightarrow$ інфраструктурне поняття.

- In May it ordered that cattle, including water buffalo, may no longer be sold in open markets for the express purpose of slaughter. (It - the environment ministry). - В травні воно наказало [ним було видано] указ, за яким рогата худоба, включно із індійським буйволом, більше не можуть надходити у вільний продаж через умисний намір забою.

В цьому випадку відбувається перенесення здатності людини керувати та давати розпорядження (order), що прямо пов'язано із віковою фізіологічною особливістю приймати рішення, на слово-позначення інфраструктурного поняття the environment ministry (Міністерство 3 питань навколишнього середовища). Це перенесення використано для відображення складного робочого процесу створення, редагування та прийняття законопроекту працівниками міністерства. 
Модель 3: фізіологічні особливості людини $\rightarrow$ абстрактні поняття.

- The few Mr Modi has carried out must be weighed against those he has botched, the areas that have gone without reform, and the sticking plasters that cover up the effects of bad policy rather than deal with their causes. - Та невелика кількість роботи виконана паном Моді повинна бути порівняна із роботою, де він працював недостатньо ретельно, із областями, котрі пішли без реформи [залишися нереформованими], та спробами залагодити наслідки поганого управління, а не його причини.

В цій моделі використано здатність людини ходити have gone в якості джерела перенесення риси на слово абстрактного поняття, що позначає політичне явище реформи. В зазначеній метафорі міститься перенесення властивостей людей на абстрактне поняття «реформа» з метою показати відсутність динамічного руху у певних сферах інфраструктури країни.

Модель 4: фізіологічні властивості людини $\rightarrow$ економічне поняття.

- Most real-estate property is vacant (neither sold nor rented out even after years), because of extremely high value and is likely to become almost dead assets. - Більшість об'єктів нерухомості $€$ вакантними (не продаються і не здаються в оренду навіть після декількох років) через надзвичайно високу вартість i, ймовірно, стануть майже мертвими активами [безперспективними].

У вищевказаному прикладі було здійснено перенесення стану фізіологічної смерті на ціль перенесення риси «активи», слово на позначення економічного поняття. Це перенесення риси було здійснено для опису перспектив продажу та орендування нерухомості за умови, коли ціна на цю нерухомість так і залишиться дуже високою.

Модель 5: фізіологічні особливості людини - просторове поняття.

- A new era begins at Uber as Travis Kalanick steps down. - Разом із крокуванням пана Каланіка вниз [відставкою пана Каланіка] для Убер розпочнеться нова ера.

В цій моделі переноситься фізіологічна властивість людини «крокувати» на просторове поняття «вниз», що у поєднанні дає метафоричний образ із переосмисленим значенням «відставка». Те, що має низхідний напрям, в більшості випадків, означає погіршення, регрес або відміну чогось. У вищевказаному прикладі мається на увазі значення відставки, тобто пониження до повного звільнення.

Модель 6: фізіологічна особливість людини - психологічний стан.

- Western leaders often shake their heads in disbelief at the sums China spends on its huge projects. - Лідери західних країн хитають головами у зневірі [із сильним подивом та скептицизмом сприймають] те, які суми грошей Китай витрачає на свої проекти. 
Вказана метафора містить в собі перенесення фізіологічної властивості на психічний процес сприйняття та реакції людини на щось. Для опису психологічної реакції чи психологічного стану людини інколи використовуються фізичні дії, що ці психічні реакції супроводжують; в наведеному прикладі такою дією виступає «хитати головою, заперечувати щось». Подібне перенесення може дуже яскраво описати психічний стан, викликаний реакцією на якусь інформацію.

Модель 7: фізіологічні особливості людини - поняття рослинного світу.

- Peaches bruise. - Персики в синцях [перетовчені].

Перенесення риси фізіологічного процесу людського організму (утворення синця в результаті пошкодження м'яких тканин пронизаних кровоносними судинами), на слово, що описує поняття рослинного світу «персик». Звісно ж персик не має кровоносної системи, а відповідно і кровоносних судин аби цей процес був можливим. Інколи для позначення характеристик, опису стану чи його змін для рослинних понять використовуються метафоричні перенесення фізіологічних властивостей людини на слово-поняття рослинного світу. Саме таке перенесення наявне у вищезазначеній моделі метафори. Фізіологічна особливість людини переноситься на рослину, що дає змогу описати стан плоду.

Модель 8: вікові фізіологічні особливості людини $\rightarrow$ соціальна характеристика людини.

- OECD citizens now in their early 30s have $7 \%$ more than members of Generation X had at that age and over $40 \%$ more than boomers enjoyed when they were similarly short in the tooth. Громадяни ОЕСР, народжені на початку 30-х років, мають на 7\% більше статків, а ніж представники покоління Х у цьому ж самому віці, та на 40 \% більше, ніж у дітей буму, коли вони мали такі ж короткі зуби [коли вони були ще такими ж молодими].

Інколи для створення відповідного метафоричного образу на позначення людини чи іiі характеристик використовують характеристики зовсім відмінних груп людей, соціальних статусів і т. д. У вказаному прикладі джерелом перенесення стала вікова фізіологічна особливість людей малого віку, коли прорізаються зуби. Ціль перенесення - соціальна характеристика людини, а саме категорія осіб, котрі належать до однієї вікової групи. Перенесення властивостей людини певного віку на соціальну характеристику людей загалом було здійснено, щоб описати вікову категорію молоді.

Модель 9: фізіологічна характеристика людини $\rightarrow$ поведінкова модель.

- Liberal or not, politicians should step slowly and carefully when it comes to complex moral issues, which, whatever your views, this certainly is. - Ліберальні чи ні, політики повинні кроку- 
вати повільно та обережно [бути дуже обережними], коли мова йде про складні моральні проблеми, які існують незалежно від їх власних поглядів.

Цей приклад метафори відображає перенесення фізичної здатності людини свідомо повільно рухатися на iï поведінкову модель, характерну в ситуаціях незнайомих або небезпечних, коли існує потреба бути дуже обережним з метою уникнення небажаних наслідків або бажання уникнути небезпеки.

Друга група метафор - метафори із джерелом перенесення фізичних особливостей людини. Ця група виявилася найменш чисельною: лише 1 модель.

Модель 1: фізичний параметр людини $\rightarrow$ поведінкова модель.

- The impulse to go it alone remains strong enough that $\mathrm{Mr} \mathrm{Xi}$, still consolidating his position as party chief, felt the need to pay it lip service. - Сам по собі поштовх рухатися самостійно і далі був достатньо потужним, що пан Ксі, котрий все ще закріплює свої позиції голови партії, вирішив відплатити за його губний сервіс [порожні обіцянки].

В цьому прикладі наявне перенесення фізичного параметру людини на іï поведінкову модель. Фізичним параметром виступають губи (lip), поведінкова модель - не виконувати обіцянки. Таке метафоричне перенесення було створено для опису особливостей поведінкової моделі (рухати губами, промовляти слова) особи, яка не дотримується даного нею слова.

До третьої групи належать метафори із джерелом перенесення психічних особливостей людини. Всього таких нараховано 4 моделі метафоричного перенесення.

Модель 1: психічна характеристика людини - об’єкт оточуючого світу.

- The painting was a faithful reproduction of the original. - Картина була вірним відтворенням [точним відтворенням] оригіналу.

Джерелом перенесення для опису предметних характеристик часто використовують якісні характеристики людини як особистості. У вищенаведеному прикладі джерелом метафоричного перенесення є особистісна характеристика людини - вірність. Ціллю перенесення виступає слово на позначення об’єкта оточуючого світу - відтворення, тобто картина-копія. Оскільки картина не є людиною, а відповідно не може бути вірною, значення слова faithful було переосмислене згідно з контекстом. Нове набуте значення цього слова «точний», тобто картинка-копія, що є точним відтворенням оригіналу.

Модель 2: психічні особливості стану людини $\rightarrow$ абстрактне поняття.

- But if this trajectory persists, a time may soon come when old folk sigh with impatience as youngsters tell them how much easier life was "when you were my age”. - Але, якщо подібна траєк- 
торія залишиться [стан речей залишиться], скоро настане час, коли літні люди будуть зітхати при словах молоді, котра каже, що жити було легше «коли ви були нашого віку».

Джерелом метафоричного перенесення у вказаному прикладі виступає психічний стан людини - несвідоме бажання дотримуватися попередньої поведінкової моделі, з метою збереження зони комфорту або небажанням змінювати щось. Ціль перенесення - слово на позначення абстрактного поняття траєкторії, що є прямим посиланням до поведінки людини. Ця метафора описує виявлену тенденцію в поведінці людей певної вікової категорії спричиненою їх психічним станом.

Модель 3: психічні особливості стану людини $\rightarrow$ соціальна характеристика людини.

- Young people left behind by migrant parents, meanwhile, are more vulnerable to being incarcerated if they have no guardian. - Тим часом, молоді люди, котрих залишили батьки-

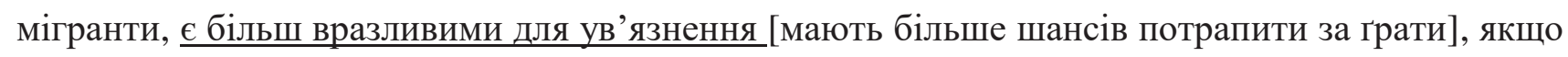
у них немає опікуна.

У цій метафорі зображено перенесення психологічної властивості людини, а саме вразливості особи, на соціальне явище, таке як ув'язнення. Перенесення подібного характеру виступає описом стану речей в країні, де діти, що залишилися без батьківського нагляду, наражаються на небезпеку бути ув'язненими. Тобто, психічна характеристика more vulnerable якраз відображає цей ризик, спричинений недостатнім наглядом.

Модель 4: психічні особливості стану людини (якісні характеристики) $\rightarrow$ фізичні параметри людини.

- Some keen-eyed people in the Philippines, monitoring the satellite data remotely, spotted the roof's lack of luminosity, showing that Mr Anoche lived under thatch (not tin). - Декілька людей iз зацікавленими очима [дуже уважних та пильних людей] на Філіпінах, віддалено спостерігаючи за даними надані супутником, примітили менш блискучий дах, що свідчило про те, що пан Аноче живе в будинку із солом'яним дахом (не металевим).

Лексика на позначення психічного стану людини чи ії особливостей також може використовуватися для опису якостей людини, іiі визначних рис, здібностей. Вищенаведений приклад демонструє модель перенесення особливостей психічного стану зацікавленості, ентузіазму, людини keеn на їі фізичний параметр еуе. У цьому перенесенні має місце переосмислення значення слова keen, що стало позначати дуже уважних та пильних людей. Мета такого метафоричного перенесення - це точний опис якості людини (пильність, уважність).

У Таблиці 1 можна побачити статистичні показники підрахунків разом із наведеними прикладами. 
Моделі перенесення антропоморфних метафор

\begin{tabular}{|l|l|c|c|l|}
\hline № & \multicolumn{1}{|c|}{ Джерело } & $\begin{array}{c}\text { Кількість } \\
\text { моделей (\%) }\end{array}$ & $\begin{array}{c}\text { Кількість } \\
\text { метафор (\%) }\end{array}$ & \multicolumn{1}{|c|}{ Приклад } \\
\hline 1 & $\begin{array}{l}\text { Фізіологічні } \\
\text { особливості }\end{array}$ & $9(64,3 \%)$ & $457(72.4 \%)$ & $\begin{array}{l}\text { Most real-estate property is vacant, because of extre- } \\
\text { mely high value and is likely to become almost dead } \\
\text { assets. }\end{array}$ \\
\hline 2 & $\begin{array}{l}\text { Психічні } \\
\text { особливості }\end{array}$ & $4(28,6 \%)$ & $133(21.1 \%)$ & $\begin{array}{l}\text { Some keen-eyed people in the Philippines, monitoring } \\
\text { the satellite data remotely, spotted the roof's lack of } \\
\text { luminosity, showing that Mr Anoche lived under thatch } \\
\text { (not tin). }\end{array}$ \\
\hline 3 & $\begin{array}{l}\text { Фізичні } \\
\text { особливості }\end{array}$ & $1(7,1 \%)$ & $41(6.5 \%)$ & $\begin{array}{l}\text { The impulse to go it alone remains strong enough that } \\
\text { Mr } \text { Xitl consolidating his position as party chief, } \\
\text { felt the need to pay it lip service. }\end{array}$ \\
\hline \multicolumn{2}{|c|}{ Всього } & $14(100 \%)$ & $631(100 \%)$ & \\
\hline
\end{tabular}

Після аналізу та розподілу метафор за моделями очевидним є те, що найчисельнішою виявилась перша група метафор із джерелом перенесення фізіологічних рис, котра налічує 9 моделей метафоричних перенесень. Друге місце посіла третя група метафор із джерелом перенесення психічних рис із 4 моделями перенесення, а найменш чисельною виявилась друга група метафор (лише 1 модель), яка джерелом перенесення мала фізичні характеристики людини. Отже, прослідковується наступна тенденція: найпродуктивнішим є метафоричне перенесення, котре в якості джерела використовує фізіологічні особливості людини. Це пояснюється тим, що фізіологічні особливості людини є поняттям ширшим за поняття фізичних або психічних особливостей, тому що описує набагато більшу кількість фізіологічних процесів, рис та особливостей протягом усього людського життя у відповідності до їх віку, під час становлення та розвитку особистості, особливостей функцій організму та їх взаємозв'язок. Фізичні ж особливості окремо описують лише фізичні параметри та характеристики організму. Слова на позначення психічних особливостей описують внутрішній світ людини та її стан, настрій, почуття та емоції

Подальшою перспективою є дослідження інших типів метафор у інформаційно-публіцистичних текстах англійською мовою.

\section{СПИСОК ЛІТЕРАТУРИ}

1. Арутюнова Н. Д. Теория метафоры: Сборник: пер. с англ., фр., нем., исп., польск. яз. Общ. ред. Н. Д. Арутюновой и М. А. Журинской. Москва: Прогресс, 1990. 512 с.

2. Бессарабова Н. Д. Метафора как языковове явление. Значение и смысл слова: художественная речь, публицистика. Под. ред. Д. Э. Розенталя. Москва: Изд-во МГУ, 1987. 200 с.

3. Бридсли М. Метафорическое сплетение. Теория метафоры: пер. с англ. Москва: Прогpecc, 1990. 201-219 c. 
4. Кабанчук Н. В. Семантична класифікація метафори в публіцистиці на матеріалі англійської та української мов. Науковий вісник Міжнародного гуманітарного університету. Сер.: Філологія. № 10, том 2. 2014.

5. Кудрявцева Л. А. Метафорические преобразование в современном языке. НДВШ, Филологические науки. № 5. 1988. 62-66 с.

6. Лакофф Д., Джонсон М. Метафори, якими ми живемо. Теорія метафори. М., 1990. 396 с.

7. Лакофф Дж. Когнитивная семантика. Язык и интеллект. Москва, 1995.

8. Скляревская Г. Н. Метафора в системе языка. СПБ. : Наука, 1993. 148 с.

9. Advanced manufacturing. The Economist Jan. 14th 2017 URL: https://www.economist.com/ news/business/21714394-making-trainers-robots-and-3d-printers-adidass-high-tech-factory-brings-production-back

10. Cash to the poor. Dec. $12^{\text {th }}$ 2013. The Economist. URL: https://www.economist.com/news/ international/21588385-giving-money-directly-poor-people-works-surprisingly-well-it-cannot-deal

11. Free exchange. The Economist. Jan. $26^{\text {th }}$ 2017. URL: https://www.economist.com/news/ finance-and-economics/21715654-policymakers-need-consider-quality-well-quantity-jobs-available

12. India's meat business. The Economist. Jun. $24^{\text {th }}$ 2017. URL: https://www.economist.com/ news/business/21723859-countrys-slaughterhouses-are-envy-rich-world-indias-huge-buffalo-meatindustry

13. The generation gain. The Economist. Oct. 28th 2017. URL: https://www.economist.com/ news/finance-and-economics/21730674-gap-closing-millennials-are-doing-better-baby-boomers-did

\section{Olha Bodnar ANTHROPOMORPHIC METAPHORS IN ENGLISH TEXTS OF THE INFORMATIONAL AND JOURNALISTIC GENRE}

Summary. The article is devoted to the study of the anthropomorphic metaphors created by transferring the features of one object to another. Since informational and journalistic texts are one of the main sources of creating new metaphors, the research, study and classification of the metaphors into types is relevant in this genre. Attention is paid to the metaphorical feature transferring models. The objective of the article includes distinguishing of the communicative and structural-semantic patterns of metaphors creation in English newspaper-journalistic texts. The material samples of the research are the metaphorical formations obtained by a continuous sampling from the editions of The Economist Newspapers published in 2013, 2014, and 2017. The author states that the most productive way of metaphors creation occurs, if the source of the borrowed feature describes human physiological conditions. The further perspective of the study involves the research on other types of metaphors in the informational and journalistic texts in English.

Keywords: metaphor, metaphorical transfer models, anthropomorphic metaphor, informational and journalistic texts, source of metaphorical transfer, target of metaphorical transfer.

\section{Vitae}

\section{Olha Bodnar}

Assistant at the Theory and Practice of Translation Department, Faculty of Foreign Languages, Vasyl' Stus Donetsk National University, Ukraine.

Correspondence: o.bodnar@donnu.edu.ua 